\title{
An Evaluation of Guideline and Recruitment Criteria of Selection of Teacher Candidates of College of Teachers Education in Oromia National Regional State of the Year 2018
}

\author{
Gadisa Wando Shaka ${ }^{1 *}$, Dawit Tadese Mekonin ${ }^{2}$, Mosisa Dejene Chala ${ }^{3}$ \\ ${ }^{1}$ Fitche College of Teachers Education, Stream of Education, Department of Psychology, Ethiopia, Oromia, \\ Fitche \\ ${ }^{2}$ Fitche College of Teachers Education, Stream of Social Science, Department of Geography, Ethiopia, Oromia, \\ Fitche \\ ${ }^{3}$ Oromia Education Bureau, Directorate of Higher Education, Team leader of Research, Ethiopia, Finfinne \\ *Corresponding Author: Gadisa Wando Shaka, Fitche College of Teachers Education, Stream of \\ Education, Department of Psychology, Ethiopia, Oromia, Fitche
}

\begin{abstract}
The objective of this study was to evaluate the guideline and recruitment criteria of selection of diploma teacher candidates of CTE in Oromia National Regional State that prepared in 2011 E.C. Descriptive design was used to conduct the study. The population of the study was 780 (178 Lecturers and 602 newly teachers candidate) from three Colleges of Teachers' Education. 137 (68 Lecturers and 69 newly teacher candidates) sample were selected using stratified sampling techniques and followed by simple random sampling method from three randomly selected colleges. The questionnaire and focused group discussion was developed to collect the necessary data from the sample. The data collected were analyzed using descriptive statistics of frequency, percentage to describe the demographic characteristics and perception of the Lecturers and for comparison of the academic achievement of the former and the newly teacher candidates range, mean and standard deviation were used. The result of the study show that the Lecturers of the colleges were accept the guideline positively in general but the way it prepared were wrong and it lacks practical assessment with specific subject matter, ethical conduct of the teaching profession and communication skill assessment and the newly teacher candidates ( of the year 2011 E.C) were lower in academic achievement with teachers made test relative to the former teacher candidates of the years 2009 and 2010 E.C. Criteria should be needs some improvement and it was suggested that Lecturers and CTE's on their behaves should do efficiently for improvement of the newly teacher candidates in academic wise through training and $O E B$ is expected to prepare the degree students for teaching profession for 2014 E.C to fulfill the teachers demand of the region and improvement should be needed to the guideline in general and to criteria specifically.
\end{abstract}

Key words: Evaluation, Selection Criteria, Teachers Candidates, Oromia

\section{INTRODUCTION}

Education is the most important instrument that facilitates human civilization in various ways and its essential tools for achieving sustainability (UNESCO, 2008). It transmits experience, findings and values accumulated over the years in the struggle to survive and develop through generations. It enables the individual and the society to be active participants in the development processes by acquainting them with new abilities, skills and changed attitudes (TGE, 1994). Education provides a fundamental base for all further human development and its availability and quality are central to the human resource development of any society. As a result, education occupies a central position in social, economic and environmental developmental issues of any country. The chief goal of the education and training policy is the cultivation of citizens with an all-round education capable of playing conscious and active role in the economic, social, and political life of the country at various levels (MOE, 1994). 
Some countries have well-established education systems which provide near universal coverage of the primary school age populations and are increasingly doing so at the secondary level (UNESCO, 2006). To attained and process education activities of any country teachers were play a vital role. In order to meet societal interest in terms of education, the demand and supply of teachers should be balanced year to year in any country.

According to UNESCO (2016), Sub-Sahara countries about 6.3 million primary teachers are needed: 2.4 million to fill new teaching posts to accommodate all children and 3.9 million to replace the teachers expected to leave the profession by 2030 .

Now days there is rapid population growth and this leads condition leads the country to invest on education in responsibly manner. Due to population growth and expanded access to education the size of primary and secondary teaching forces across the world and how numbers have changed over time (UNESCO, 2006). It also examines the potential impact on pupil-teacher ratios and learning. Our country Ethiopia is one of the Sub-Sahara countries and expressed by rapid population growth and access of education is improved time to time. In Ethiopia about $86 \%$ of primary school-age children are enrolled in school and the recruitment rate of teachers has increased by an average of about $2.4 \%$ in recent years. Nevertheless, primary classrooms remain massively overcrowded, with an average of 64 pupils per teacher. The situation may deteriorate as the primary school-age population is estimated to increase by $18 \%$ - from 15.7 million in 2014 to 18.5 million in 2030 . To reach all children by that deadline, the country needs to recruit $7.4 \%$ more teachers per year (UNESCO, 2016).

Oromia is one of the huge regional states which educational activities had been processed from the part of Ethiopia. To fulfill and answering the societal interest in terms of education, the regional government and OEB as a Bureau have actively invest on the education activities as whole. One of the responsibilities of OEB is to select, trained and placed elementary teachers. To fill the human power in general and teachers specifically sufficiently for schools the OEB have been placed teachers year to year. In any country to select a new teacher candidate there should be selection recruitment from the large competent. For this reason the Bureau have preparing guideline and recruitment of selection for diploma teacher's candidates to train in colleges of teacher's education of the region year to year. Therefore this research focuses on the evaluation of guideline and recruitment criteria of diploma teachers' candidate that prepared for 2018/2011 E.C.Even though college training may improve the knowledge, skill and attitude of the candidate but miss selection of the candidate may lead to teaching inappropriate candidate and prepared for future teacher and this is an alarm for OEB and for all stakeholders. Mathis and Jackson (2010) stated that good training will not make up for bad selection. When people without the appropriate aptitudes are selected, employers will have difficulty training them to do those jobs that they do not fit. There is no assessment and investigation while preparing the guideline to invite only grade 12 students take as a candidate of teacher for the year 2018/2011 E.C for Oromia CTE's. Additionally in the fitche colleges of Teachers education in 2008 and 2009 the least GPA scored by students was 1.6 and 1.5 respectively and the highest GPA was 4.00 and 4.00 respectively but in 2018/2011 E.C the least score was 1.00 and the highest score of students was 3.6, the researchers take this as the gap of the study.

\subsection{Research Questions}

This research was answered the following basic research questions:

1. What is the perception of college's lecturers towards the recruitment criteria and the guideline?

2. What extent the newly teachers candidate (2018/2011 E.C) achieve academically in relative to the former teachers candidate (2016/2009 and 2017/2010 E.C) in classroom test?

3. What are the gaps those have to be incorporate in the guideline and its impact as a criterion?

4. What are the contributions of colleges of teacher's education to capacitate the teachers candidate to be competent teachers?

\subsection{Objectives of the Study}

The general objective of this study is to evaluation the newly guideline and recruitment 
Criteria of for fresh teachers' candidate of CTEs' of Oromia National Regional State.

Specifically the study has the following objectives;

1. To describe the perception of college's Lecturers towards the recruitment criteria and the guideline

2. To compare and contrast the extent of academic achievement of the newly teachers candidate (2018/2011 E.C) with the former teachers candidate (2016/2009 E.C and 2017/ 2010 E.C) in classroom test GPA?

3. To show the basic gaps that should incorporate in the guideline and its impact as a criterion?

4. To show the role of CTE in capacitates the teacher's candidate to be competent teachers?

\subsection{Abbreviations}

ATEE: Association for Teachers Education in Europe

BOFEDO: Finance and Economic Development Bureau of Oromia Regional Government

CTE: College of Teachers Education

E.C: Ethiopian Calendar

FCTE: Fitche College of Teachers Education

GIS: Geographical Information System

GPA: Grade Point Average

ISCED: International Standard Classification of Education

KSAs: Knowledge, Skills and Abilities

MOE: Ministry of Education

NCLB: No Child Left Behind

NCTE: Nekemte College of Teachers Education

OEB: Oromia Education Bureau

OECD: Organization of Economic Cooperative and Development

R: Range

SD: Standard Deviation

SPSS: Statistical Package for Social Science

SSNCTE: Sebete Special Need College of Teachers Education

TC: Teacher Candidates

UNESCO: United Nation Education, Science and Cultural Organization

\section{MeTHODS AND MATERIAL}

The study was following mixed approach of quantitative and qualitative approach of descriptive design. The approach was selected for its appropriateness to the nature of the study because more data was collected from the sample of the study. That is why the study the researchers decided to used descriptive research design to evaluate the guideline and recruitment criteria of teacher candidates of CTE of Oromia National regional State of the year 2018/2011 E.C.

Description of the study area: Oromia is the largest National Regional State in the Federal Democratic Republic of Ethiopia. The region lies between $3^{0} 40^{\prime}$ and $10^{0} 35^{\prime}$ North $34^{\circ} 05^{\prime}$ to $43^{\circ} 11^{\prime}$ East and covers a geographic area of about 364,606 square kilometers (BoFEDO GIS 2010). Therefore the study area mainly focused on the Colleges of Teachers Education in Oromia National Regional State. 
Population, sample and sampling techniques: After the year 2018/2011 E.C inOromia National Regional State there are 13 CTE. From those in order to manageable the study three CTE was selected using simple random sampling method. In the three selected CTE namely, Fitche, Nekemte, and Sebeta there are 602 (311 male and 291) newly teacher candidates and 178 (162 male and 16 female) lecturers whose participate on the selection of the newly teacher candidates. The total population of the study was 780 . From the total population the researchers select and 68 lecturers $(66$ male and 2 female) using simple random sampling methods and 69 newly teacher candidates for the small group of discussion using stratified sampling method and followed by simple random sampling technique. Stratified sampling method was used to include the sample from all departments and after that simple random sampling technique is applied using Krejie and Morgan (1970) sampling formula as follows. Totally 137 respondents was selected as sample of the study.

$\mathrm{S}=\mathrm{X}^{2} \mathrm{~N} \mathrm{P}(1-\mathrm{P} 0) \div \mathrm{d}^{2}(\mathrm{~N}-1)+\mathrm{X}^{2} \mathrm{P}(1-\mathrm{P})$. Where: $\mathbf{S}=$ required sample size, $\mathbf{X}^{2}=$ the table value of chi-square for 1 degree of freedom at the desired confidence level (3.841), $\mathbf{N}=$ the population size, $\mathbf{P}=$ the population proportion (assumed to be 0.50 ) and $\mathbf{d}^{2}=$ the degree of accuracy expressed as a proportion (.05).

Table1. Population and sample of the study

\begin{tabular}{|l|l|l|l|l|l|l|l|}
\hline \multirow{2}{*}{$\begin{array}{l}\text { Name of } \\
\text { CTE }\end{array}$} & Respondents & \multicolumn{2}{l|}{ Population } & \multicolumn{2}{l|}{ Sample size } \\
\cline { 2 - 8 } & & Male & Female & Total & Male & Female & Total \\
\hline \multirow{5}{*}{ Nekemte } & Lecturers & 53 & 4 & 57 & 22 & 1 & 23 \\
\cline { 2 - 8 } & Teacher Candidates & 160 & 194 & 354 & 22 & 17 & 39 \\
\cline { 2 - 8 } & Total & $\mathbf{2 1 3}$ & $\mathbf{1 9 8}$ & $\mathbf{4 1 1}$ & $\mathbf{4 4}$ & $\mathbf{1 8}$ & $\mathbf{6 2}$ \\
\hline \multirow{5}{*}{ Fitche } & Lecturers & 55 & 6 & 61 & 22 & 0 & 22 \\
\cline { 2 - 8 } & Teacher Candidates & 55 & 41 & 96 & 7 & 5 & 12 \\
\cline { 2 - 8 } & Total & $\mathbf{1 1 0}$ & $\mathbf{4 7}$ & $\mathbf{1 5 7}$ & $\mathbf{2 9}$ & $\mathbf{5}$ & $\mathbf{3 4}$ \\
\hline \multirow{5}{*}{ Gebeta } & Lecturers & 54 & 6 & 60 & 22 & 1 & 23 \\
\cline { 2 - 8 } & Teacher Candidates & 96 & 56 & 152 & 13 & 5 & 18 \\
\cline { 2 - 8 } & Total & $\mathbf{1 5 0}$ & $\mathbf{6 2}$ & $\mathbf{2 1 2}$ & $\mathbf{3 5}$ & $\mathbf{6}$ & $\mathbf{4 1}$ \\
\cline { 2 - 8 } & Lecturers & $\mathbf{1 6 2}$ & $\mathbf{1 6}$ & $\mathbf{1 7 8}$ & $\mathbf{6 6}$ & $\mathbf{2}$ & $\mathbf{6 8}$ \\
\cline { 2 - 8 } & Teacher Candidates & $\mathbf{3 1 1}$ & $\mathbf{2 9 1}$ & $\mathbf{6 0 2}$ & $\mathbf{4 2}$ & $\mathbf{2 7}$ & $\mathbf{6 9}$ \\
\cline { 2 - 8 } & Total & $\mathbf{4 7 3}$ & $\mathbf{3 0 7}$ & $\mathbf{7 8 0}$ & $\mathbf{1 0 8}$ & $\mathbf{2 9}$ & $\mathbf{1 3 7}$ \\
\hline
\end{tabular}

Sources of Data: The researchers used primary and secondary sources of data, the primary source were lecturers and newly TC of the CTE and the secondary source is the document that serve as a guideline and recruitment criteria used for selecting TC in 2018/2011 E.C. In addition to this, the students' grade report of 2018/2011 E.C. from registrar of CTE was used as secondary source.

Tools of the Study: Gathering necessary data for the study was done by using questionnaire (Open ended and closed ended) and focused group discussion. The questionnaire is used to collect the necessary data from lecturers and focused group discussion is for newly TC.

Variables of the Study: The independent variable of the study isguideline and recruitment criteria of CTE newly teachers' candidate that prepared in 2018/2011 E.C. and the dependent one isacademic achievement of the teacher candidates from 2016-2018/2009-2011E.C. as measured by GPA of their first semester, Perception of lecturers toward the guideline document, role of CTE and impacts of the guideline.

Methods of data analysis: The data collected from lecturers with questionnaires was coded and entered into the computer for analysis using SPSS program version-24 and the teacher candidate's achievement as GPA as well. The response of small group discussion of newly teacher candidates was used as triangulations that support the quantitative data analysis results. In order to describe the demographic characteristics of respondents, perception of lecturers towards the guideline as well as the impacts of the guideline descriptive statistic of frequency and percentage was done. For comparison of classroom academic achievement between the newly and the former teacher candidatesfrom the years 2016-2018/2009-2011 E.C. descriptive statistics of range, mean, minimum, maximum and standard deviation was applied. 


\section{RESUltS}

\subsection{Demographic Characteristics of the Respondents}

Under table 2 and 3 demographic characteristics of the respondents like sex, work experience, level of education and years of participation in selection teacher candidates have been describe.

Table2. The Characteristics of the Respondents

\begin{tabular}{|c|c|c|c|c|c|c|c|c|c|c|c|c|c|c|c|}
\hline \multirow{2}{*}{$\begin{array}{l}\mathrm{N} \\
\underline{\mathrm{o}} \\
\end{array}$} & \multirow{3}{*}{$\begin{array}{l}\text { Respo } \\
\text { nse }\end{array}$} & \multicolumn{14}{|c|}{ Variables } \\
\hline & & \multicolumn{3}{|l|}{ Sex } & \multicolumn{5}{|c|}{ Level of education } & \multicolumn{6}{|c|}{ Work Experience } \\
\hline & & M & $\mathrm{F}$ & $\begin{array}{l}\text { Tot } \\
\text { al }\end{array}$ & $\begin{array}{l}\text { Diplo } \\
\text { ma }\end{array}$ & $\begin{array}{l}\mathrm{BA} / \mathrm{B} \\
\mathrm{SC}\end{array}$ & $\begin{array}{l}\mathrm{MA} / \mathrm{M} \\
\mathrm{SC}\end{array}$ & $\begin{array}{l}\text { Oth } \\
\text { ers }\end{array}$ & $\begin{array}{l}\text { Tot } \\
\text { al }\end{array}$ & $\begin{array}{l}1- \\
5\end{array}$ & $\begin{array}{l}6- \\
1 \\
0\end{array}$ & $\begin{array}{l}11 \\
- \\
15\end{array}$ & $\begin{array}{l}16 \\
- \\
20\end{array}$ & $\begin{array}{l}>2 \\
0\end{array}$ & $\begin{array}{l}\text { Tot } \\
\text { al }\end{array}$ \\
\hline \multirow[t]{2}{*}{1} & No & 66 & 2 & 68 & 4 & 8 & 56 & 0 & 68 & 4 & 4 & 8 & 14 & 38 & 68 \\
\hline & $\%$ & $\begin{array}{l}97 . \\
05\end{array}$ & $\begin{array}{l}2.9 \\
4\end{array}$ & 100 & 5.9 & 11.8 & 82.4 & 0 & $\begin{array}{l}100 \\
.0\end{array}$ & $\begin{array}{l}5 . \\
9\end{array}$ & $\begin{array}{l}5 . \\
9\end{array}$ & $\begin{array}{l}11 \\
8\end{array}$ & $\begin{array}{l}20 . \\
6\end{array}$ & $\begin{array}{l}55 . \\
9\end{array}$ & $\begin{array}{l}100 \\
.0\end{array}$ \\
\hline
\end{tabular}

Source: Survey of 2019 from CTE'S

As can be seen from table 2 above the male respondents were 66(97.05\%) and female respondents were 2(2.94\%). This implies thatthose female lecturers are very little in number in CTE'S. Concerning level of education, 4(5.9\%) were diploma, 8(11.8\%), 56(82.4\%) were first degree and second degree holders respectively. This data shows that more of the lecturers were masters' holders and they full fill the higher education criteria for training of diploma as well as degree teacher' candidates. More of the respondents' experience was above 20 years that account 38(55.9\%) respondents. So, this implies that the lecturers had sufficient work experience.

Table3. The Characteristics of the Respondents

\begin{tabular}{|l|l|l|l|l|l|l|l|}
\hline \multirow{2}{*}{ No } & \multirow{2}{*}{ Response } & \multicolumn{6}{|c|}{ Variables } \\
\cline { 3 - 8 } & & \multicolumn{6}{|c|}{ Year of respondents participated in selecting TC } \\
\cline { 3 - 8 } & $1-2$ & $3-4$ & $5-6$ & $7-8$ & Above 9 & Total \\
\cline { 2 - 8 } & No & 14 & 2 & 18 & 8 & 26 & 68 \\
\cline { 2 - 9 } & $\%$ & 20.6 & 2.9 & 26.5 & 11.8 & 38.2 & 100.0 \\
\hline
\end{tabular}

Source: Survey of 2019 from CTE'S

From the above, table 3 regarding years of respondents participated in selection of TC, about 14 $(20.6 \%), 2(2.9 \%), 18(26.5 \%), 4(11.8 \%)$ and $26(38.2 \%)$ of the respondents were participated from 1-2 years,3-4 , 5-6, 7-8 and above 9 years respectively. This result implies that more 26 (38.2\%) lecturers were experienced in selecting teacher candidate for more than 9 years; this indicated that they are familiar with different selection guidelines and criteria.

\subsection{Perception of Lecturers towards the Guideline Recruitment Criteria}

Under this table perception of lecturers towards the guideline and the criteria in the guideline was presented.

Table4. Perception of lecturers towards the guideline document

\begin{tabular}{|c|c|c|c|c|c|c|c|c|c|}
\hline \multirow[t]{3}{*}{ No } & \multirow{3}{*}{ Variable } & \multicolumn{8}{|c|}{ Response } \\
\hline & & \multicolumn{2}{|c|}{ Yes/positively } & \multicolumn{2}{|c|}{ No/negatively } & \multicolumn{2}{|c|}{ Miss } & \multicolumn{2}{|c|}{ Total } \\
\hline & & No & $\%$ & $\mathrm{No}$ & $\%$ & No & $\%$ & $\mathrm{No}$ & $\%$ \\
\hline 1 & $\begin{array}{l}\text { Are you satisfied on how the guideline } \\
\text { and recruitment criteria for CTE are } \\
\text { prepared in } 2011 \text { E.C? }\end{array}$ & 32 & 47.1 & 34 & 50 & 2 & 2.9 & 68 & 100 \\
\hline 2 & $\begin{array}{l}\text { How do lecturers or your staff mate } \\
\text { react to recruitment criteria of diploma } \\
\text { teacher's selection? }\end{array}$ & 44 & 64.7 & 22 & 32.4 & 2 & 2.9 & 68 & 100 \\
\hline 3 & $\begin{array}{l}\text { Is the guideline tend to recruit } \\
\text { academically high achiever application? }\end{array}$ & 22 & 32.4 & 40 & 58 & 6 & 8.8 & 68 & 100 \\
\hline
\end{tabular}


An Evaluation of Guideline and Recruitment Criteria of Selection of Teacher Candidates of College of Teachers Education in Oromia National Regional State of the Year 2018

\begin{tabular}{|l|l|l|l|l|l|l|l|l|l|}
\hline 4 & $\begin{array}{l}\text { Are the candidates having an interest to } \\
\text { be a teachers? }\end{array}$ & 38 & 55.9 & 30 & 44.1 & 0 & 0 & 34 & 100 \\
\hline 5 & $\begin{array}{l}\text { Is there any evidence put on the } \\
\text { guideline as a criterion to identify the } \\
\text { interest of the candidate to be a teacher? }\end{array}$ & 8 & 11.7 & 60 & 88.3 & 0 & 0 & 34 & 100 \\
\hline
\end{tabular}

Source: Survey of 2019 from CTE'S

According to table 4 of variable one $32(47.1 \%)$ of respondents were satisfied on the preparation of the guideline recruitment criteria of selection and $34(50 \%)$ of them were not satisfied on the preparation of the guideline. Therefore it is possible to conclude from this, the way in which the guideline recruitment criteria prepared is wrong.

According to the open ended responses more lecturers were explain that during preparation of the guideline in general and the recruitment criteria specifically lecturers were not participated rather than the OEB invite college administration in preparation of the guideline.

Variables two of table 3 revealed that $44(64.7 \%)$ of lecturers were react positively towards on the selection criteria of the guideline and $22(32.4 \%)$ of the respondents were react negatively on the selection criteria of the guideline. So this implies that more of the respondents were agree on the selection criteria of the guideline.

Even though more lecturers were positively accepted the guide line but lecturers response of open ended questionnaire shows that more of themcriticized that the recruitment criteria was not invite higher academic achiever.

Item three on the above table revealed that $40(58 \%)$ of the respondents were responded that guideline recruitment criteria was not invite higher academic achiever on the other hand $22(32.4 \%)$ of the lecturers were agree that the recruitment criteria of selection was invite the higher academic achiever. Therefore, this implies more respondents were agreeing on this issue that the recruitment criteria of the guideline not invite higher academic achiever.

The response from newly TC of focused group discussion regarding the above issue that; higher academic achiever students haven't an interest to be a teacher because of currently paid of monthly salary of teachers and the like in teaching profession. The criteria itself guide to invite lower academic achiever, therefore it needs some amendment. The condition in teaching profession is unattractive that is why higher academic achiever were not interested.

The fourth variable of table 4 revealed that $38(55.9 \%)$ of the respondents were responded that the candidate for teachers have an interest to be a teachers. On the other hand 30(44.1\%) of them were responded that the candidate have no interest to be a teachers. So, this implies that more of the respondents were agree on the interest to be a teaching profession.

The response from focused group discussion of TC; more of the newly teachers candidate have an interest to be a teacher for so many reasons: Teaching profession is a fundamental for all profession, to cultivate learned society, to change our society from the level of illiterate to literate, for proudness of teaching profession because teacher is a father for all people and profession as well as knowledgeable throughout his/her lifespan.

The last variable of the above table shows that $8(11.7 \%)$ of the respondents realized that there isevidence put on the guideline as a criterion to identify the interest of the candidate to be a teacher and $60(88.7 \%)$ of the respondents ensure that there is no evidence put on the guideline as a criterion to identify the interest of the candidate to be a teacher. Therefore this result shows that there is no evidence put on the guideline as a criterion to identify the interest of the candidate to be a teacher.

\subsection{The Criteria in the Guideline}

Under this table, the criteria in the guideline was assessed and presented

Table5. The criteria in the guideline

\begin{tabular}{|l|l|l|l|l|l|l|l|l|l|l|l|l|}
\hline No & Variable & $\begin{array}{l}\text { Strongly } \\
\text { Agree }\end{array}$ & \multicolumn{2}{l|}{ Agree } & \multicolumn{2}{l|}{ Undecided } & \multicolumn{2}{l|}{ Disagree } & \multicolumn{2}{l|}{$\begin{array}{l}\text { Strongly } \\
\text { Disagree }\end{array}$} & \multicolumn{2}{|l|}{ Total } \\
\cline { 3 - 11 } & No & $\%$ & No & $\%$ & No & $\%$ & No & $\%$ & No & $\%$ & No & $\%$ \\
\hline
\end{tabular}


An Evaluation of Guideline and Recruitment Criteria of Selection of Teacher Candidates of College of Teachers Education in Oromia National Regional State of the Year 2018

\begin{tabular}{|l|l|l|l|l|l|l|l|l|l|l|l|l|}
\hline 1 & $\begin{array}{l}\text { Guideline } \\
\text { components } \\
\text { draw the thics } \\
\text { of the teaching } \\
\text { professions }\end{array}$ \\
2 & 2 & 2.9 & 10 & 14.7 & 16 & 23.5 & 28 & 41.2 & 12 & 17.6 & 68 & 100 \\
\hline $\begin{array}{l}\text { The } \\
\text { guidelineinclude } \\
\text { professional } \\
\text { advance the } \\
\text { communicative } \\
\text { skills of student } \\
\text { teachers }\end{array}$ & 2 & 2.9 & 6 & 9.7 & 14 & 22.6 & 28 & 41.18 & 18 & 26.47 & 68 & 100 \\
\hline 4 & $\begin{array}{l}\text { The guideline to } \\
\text { provide } \\
\text { effective } \\
\text { teachers } \\
\text { educators in } \\
\text { required } \\
\text { quantity }\end{array}$ \\
\hline 5 & $\begin{array}{l}\text { The guideline } \\
\text { offers Inclusive } \\
\text { Education } \\
\text { (Special } \\
\text { Education) }\end{array}$ \\
\hline 6 & $\begin{array}{l}\text { The guideline } \\
\text { designed to } \\
\text { allow a variety } \\
\text { of teaching, } \\
\text { learning and } \\
\text { assessment } \\
\text { methods to be } \\
\text { incorporated, as } \\
\text { appropriate, into } \\
\text { the area of study }\end{array}$ \\
\hline
\end{tabular}

According to the above table 5, 2.9\% and $14.7 \%$ of the lecturers were realized that strongly agree and agree respectively on the content of the guideline was focus on the ethics of the teaching professions. On the other hand 28(41.2) and 12(17.6\%) of the respondents were disagree and strongly disagree thatthe guideline criteria was not considering ethics of teaching professions. Therefore it's concluded from this point, the guideline was not attachment with the professional ethics of teaching while preparing. The second item of the above table shows that 2(2.9\%) and 6(9.7\%) of the respondents were strongly agree and agree respectively that the guideline was assess communicative skill of TC but $28(41.18 \%)$ and $18(26.47 \%)$ of the lecturers were disagree and strongly disagree respectively that the guideline was not assessed the communication skill of teachers candidate as a criteria. This result implies that the guideline was not assessing communication skill of the teacher candidates in good manner.2(5.9\%) and $18(26.5 \%)$ of the respondents were strongly agree and agree respectively that the criteria in the guideline was invite effective and quantity teachers candidate, on the other hands $24(35.3 \%)$ and $8(11.8 \%)$ of them were disagree and strongly disagree that the criteria was not invite effective and quantity teachers. This result shows that the criteria in the guideline doesn't incorporate to select effective and quantity teachers in accordance to demand of the region.10(15.2\%) and $26(39.4 \%)$ of lecturers were strongly agree and agree respectively that the guideline concern about the inclusive education but $12(18.2 \%)$ of the respondents were disagree on the above issue. This implies that the guideline was invite inclusive education and serves for anybody whose fulfill the criteria.The last variable on the above table revealed that $4(5.9 \%)$ and $12(17.6 \%)$ of the respondents were strongly agree and agree respectively that the guideline is designed to inclusive of different teaching and assessment methods in subject specific.On the other hand $18(26.5 \%)$ and $22(32.4 \%)$ of them were strongly disagree and disagree that there is no different teaching and assessment methods 
An Evaluation of Guideline and Recruitment Criteria of Selection of Teacher Candidates of College of Teachers Education in Oromia National Regional State of the Year 2018

incorporate in the guideline with subject specific. This result shows that there is no practical teaching methods and assessment in the guideline with specific area of subject.

\subsection{Responses of Lecturers on the Newly Teacher Candidates` Performance During Selection}

This part of table 6 and 7 shows the response of the lecturers on the performance of the newly selected candidates during selection.

Table6. Responses of lecturers regarding TC performance during Selection

\begin{tabular}{|c|c|c|c|c|c|c|c|c|c|c|c|c|c|}
\hline \multirow[t]{3}{*}{ No } & \multirow[t]{3}{*}{ Variable } & \multicolumn{12}{|c|}{ Responses } \\
\hline & & \multicolumn{2}{|c|}{ SA } & \multicolumn{2}{|l|}{$\mathrm{A}$} & \multicolumn{2}{|c|}{ UD } & \multicolumn{2}{|l|}{$\mathrm{D}$} & \multicolumn{2}{|c|}{ SD } & \multicolumn{2}{|c|}{ Total } \\
\hline & & $\mathrm{N}$ & $\%$ & $\mathrm{~N}$ & $\%$ & $\mathrm{~N}$ & $\%$ & $\mathrm{~N}$ & $\%$ & $\mathrm{~N}$ & $\%$ & $\mathrm{~N}$ & $\%$ \\
\hline 1 & $\begin{array}{l}\text { The ability to } \\
\text { convey } \\
\text { knowledge }\end{array}$ & 22 & 32.4 & 28 & 41.1 & 10 & 14.7 & 8 & 11.8 & 2 & 2.9 & 68 & 100 \\
\hline 2 & $\begin{array}{l}\text { The ability to } \\
\text { convey } \\
\text { Communication } \\
\text { skills }\end{array}$ & 20 & 29.4 & 28 & 41.2 & 10 & 14.7 & 10 & 14.5 & - & - & 68 & 100 \\
\hline 3 & $\begin{array}{l}\text { Knowledge of } \\
\text { the subject } \\
\text { matter }\end{array}$ & 26 & 39.4 & 18 & 27.3 & 8 & 12.1 & 12 & 18.2 & 2 & 3.0 & 66 & 100 \\
\hline
\end{tabular}

Source: Field Survey of 2019 from CTE's

As table 6 above shows that, majority 28 and $22(41.1 \%$ and $32.4 \%)$ of the respondents forwarded agree and strongly agree respectively, on that the newly TC ability to convey knowledge during selection while about $8(11.8 \%)$ of them responded disagree on the newly candidates ability to convey knowledge during selection. But, about 2(2.9\%) of the respondents argued that strongly disagree on the same idea reflected above. This implies that more $50(73.5 \%)$ of the respondents were recognized the newly selected teachers` candidates had tested with their ability to convey knowledge during selection.

Moreover, about 28 and 20 (41.2\% and 29.4\%) of the respondents were agree and strongly agree respectively, on that the new teachers` candidate ability to convey Communication skills whereas about $10(14.5 \%)$ of them forwarded disagree on newly teachers' candidate ability to convey Communication skills. This result shows that almost about $48(70.6 \%)$ of the lecturers were convinced that the newly TC was assessed their communication skill but still there is a gap while selection. Further, about 26 and 18 (39.4\% and 27.3\%) of the respondents were strongly agree and agree respectively on that the candidates have, knowledge of the subject matter while about 8,12 and 2 $(18.2 \%, 12.1 \%$ and $3 \%)$ of the respondents argued undecided, disagree and strongly disagree respectively on that the candidates have knowledge of the subject matter. This indicates that about 44 $(66.6 \%)$ of the respondents were accepted the newly selected candidates' knowledge of subject matter.

Table7. Responses of lecturers regarding TC performance during Selection

\begin{tabular}{|c|c|c|c|c|c|c|c|c|c|c|c|c|c|}
\hline \multirow[t]{3}{*}{ No } & \multirow{3}{*}{ Variable } & \multicolumn{12}{|c|}{ Responses } \\
\hline & & \multicolumn{2}{|l|}{ SA } & \multicolumn{2}{|l|}{$\mathrm{A}$} & \multicolumn{2}{|c|}{ UD } & \multicolumn{2}{|l|}{$\mathrm{D}$} & \multicolumn{2}{|c|}{ SD } & \multicolumn{2}{|c|}{ Total } \\
\hline & & $\mathrm{N}$ & $\%$ & $\mathrm{~N}$ & $\%$ & $\mathrm{~N}$ & $\%$ & $\mathrm{~N}$ & $\%$ & $\mathrm{~N}$ & $\%$ & $\mathrm{~N}$ & $\%$ \\
\hline 1 & $\begin{array}{l}\text { The criteria is define } \\
\text { clear }\end{array}$ & 20 & 30.3 & 16 & 24.2 & 18 & 27.5 & 12 & 18.2 & - & - & 66 & 100 \\
\hline 2 & $\begin{array}{l}\text { The selection process } \\
\text { were run without } \\
\text { regular central control } \\
\text { mechanism }\end{array}$ & 16 & 23.5 & 16 & 23.5 & 18 & 26.5 & 8 & 11.8 & 10 & 14.7 & 68 & 100 \\
\hline 3 & $\begin{array}{l}\text { Minimum learnig } \\
\text { competence tests }\end{array}$ & 26 & 38.2 & 22 & 32.4 & 12 & 17.6 & 8 & 11.8 & - & - & 68 & 100 \\
\hline
\end{tabular}


Source: Field Survey of 2019 from CTE's

In the table 7 of the first variable, about 20 and 16 (30.3\% and $24.2 \%)$ of the respondents responded strongly agree and agree respectively on the idea which indicate that the newly candidates were selected with clear defined criteria while about 18 and $12(27.4 \%$ and $18.2 \%)$ of them argued undecided and disagree respectively on the same idea mentioned above. This is to say that almost more than half percent 36 (54.5\%) of the respondents were realized that newly TC was selected with clearly defined criterion.

According to the above table of item two 16 and 16 (23.5\% and 23.5\%) of the respondent were strongly agree and agree respectively that the selection process were run without regular central control mechanism but 8 and $10(11.8 \%$ and $14.7 \%)$ of them were disagree and strongly disagree respectively that the selection process were run without regular central control mechanism, however $18(26.5 \%)$ of the respondents were either of the two. This result shows that there is no regular central control while selection processes were ongoing. With item three of the above table revealed that 26 and $22(38.2 \%$ and $32.4 \%)$ of the respondents were ensure that the newly candidate were administered with a test that directly related to minimum learning competency but $8(11.8 \%)$ of the respondents ensure that the test had no relationship with minimum learning competency. It's possible to conclude that more of the respondents realize that the test prepared has depended on the minimum learning competency.

\subsection{Lecturers Responses on Performance of Newly Teacher Candidates in Training Processes}

Table8. Lecturers Responses on Performance of newly TC in Training Processes

\begin{tabular}{|c|c|c|c|c|c|c|c|c|c|c|c|c|c|}
\hline \multirow[t]{3}{*}{ No } & \multirow[t]{3}{*}{ Variable } & \multicolumn{12}{|c|}{ Responses } \\
\hline & & \multicolumn{2}{|c|}{ SA } & \multicolumn{2}{|c|}{$\mathrm{A}$} & \multicolumn{2}{|c|}{ UD } & \multicolumn{2}{|l|}{$\mathrm{D}$} & \multicolumn{2}{|l|}{ SD } & \multicolumn{2}{|c|}{ Total } \\
\hline & & $\mathrm{N}$ & $\%$ & $\mathrm{~N}$ & $\%$ & $\mathrm{~N}$ & $\%$ & $\mathrm{~N}$ & $\%$ & $\mathrm{~N}$ & $\%$ & $\mathrm{~N}$ & $\%$ \\
\hline 1 & $\begin{array}{l}\text { Promote } \\
\text { reflection, } \\
\text { discussion, simulation and } \\
\text { analyses of cases and } \\
\text { situations }\end{array}$ & 18 & 26.5 & 20 & 29.4 & 14 & 20.6 & 14 & 20.6 & 2 & 2.9 & 68 & 100 \\
\hline 2 & $\begin{array}{l}\text { Process and system of } \\
\text { teaching and learning in } \\
\text { CTE's introduce teacher's } \\
\text { student to the concept of the } \\
\text { continuum of teacher } \\
\text { education and develop } \\
\text { student teachers' capacity to } \\
\text { plan their learning path. }\end{array}$ & 14 & 20.8 & 34 & 50 & 10 & 14.7 & 10 & 14.5 & - & - & 68 & 100 \\
\hline 3 & $\begin{array}{l}\text { Focus for personal and } \\
\text { professional development } \\
\text { during the newly induction } \\
\text { period of first year. }\end{array}$ & 18 & 26.5 & 26 & 38.2 & 10 & 14.7 & 12 & 17.6 & 2 & 2.9 & 68 & 100 \\
\hline 4 & $\begin{array}{l}\text { Processes and systems in } \\
\text { CTE's facilitate the } \\
\text { development of the core } \\
\text { values and professional } \\
\text { commitments which are set } \\
\text { out in the Professional } \\
\text { Conduct for Teachers. }\end{array}$ & 18 & 26.5 & 26 & 38.2 & 20 & 29.4 & - & - & 4 & 5.9 & 68 & 100 \\
\hline 5 & $\begin{array}{l}\text { In teaching learning process } \\
\text { the candidate have } \\
\text { motivated interest for } \\
\text { teaching profession }\end{array}$ & 12 & 17.6 & 14 & 20.6 & 22 & 32.4 & 14 & 20.6 & 6 & 8.8 & 68 & 100 \\
\hline 6 & $\begin{array}{l}\text { When you compare, the } \\
\text { new student teachers } \\
\text { achievement in classroom } \\
\text { learning was higher than the } \\
\text { former students teachers }\end{array}$ & 6 & 8.8 & 10 & 14.7 & 20 & 29.4 & 16 & 23.5 & 16 & 23.5 & 68 & 100 \\
\hline
\end{tabular}

Source: Field Survey of 2019 from CTE's 
Table 8 , above reveals that about 14,14 and $2(20.6 \%, 20.6 \%$ and $2.9 \%)$ of the respondents forwarded undecided, disagree and strongly disagree respectively, on that the newly TC promote reflection, discussion, simulation and analysis of cases and situations during training process while about 20 and $18(29.4 \%$ and $26.5 \%)$ of the respondents agree and strongly agree respectively regarding the newly TC as to promote reflection, discussion, simulation and analysis of cases and situations during training process. This finding shows that almost 38 (55.9\%) of the respondents were argued that the newly TC have the potential to promote reflection, discussion, simulation and analysis of cases and situations during training process

Further, about 14 and $34(20.8 \%$ and 50\%) of the respondents revealed that strongly agree and agree respectively that process and system of teaching and learning in CTE's introduce teacher's student to the concept of the continuum of teacher education and develop student teachers' capacity to plan their learning path during training whereas about $10(14.5 \%)$ of the respondents were disagree to the same idea mentioned above. This implies that the process and system of teaching and learning methods introduced in the colleges were, more depend on the TC in order to develop their capacity. Moreover about 18 and $26(26.5 \%$ and $38.2 \%)$ of respondents were strongly agree and agree respectively realized that newly TC were focus for personal and professional development during induction period while about 12 and $2(17.6 \%$ and $2.9 \%)$ of respondents forwarded disagree and strongly disagree that newly TC were focus for personal and professional development during induction period. This result shows that the majority $44(64.7 \%)$ of the respondents were realized that, newly TC was focus on personal and professional development during induction period but it not fully applies.

Similarly, 18 and 26 (26.5\% and 38.2\%) of respondents were strongly agree and agree respectively that processes and systems in CTE's facilitate the development of the core values and professional commitments which are set out in the professional conduct for teachers whereas 20 and 4 (29.4\% and $5.9 \%$ ) of the respondents were forwarded undecided and strongly disagree respectively, that processes and systems in the CTE's is facilitate the development of the core values and professional commitments which are set out in the professional conduct for teachers. According to this finding more respondents about $44(64.7 \%)$ were realized that processes and systems in CTE's facilitate the development of the core values and professional commitments which are set out in the professional conduct for teachers. Likewise, about 12 and 14 (17.6\% and 20.6\%) of respondents were strongly agree and agree respectively that the newly TC, have motivated interest for teaching profession in teaching learning process. On the other hands 14 and $6(20.6 \%$ of and $8.8 \%)$ of respondents were disagree and strongly disagree respectively, that in teaching learning process the newly TC, have motivated interest for teaching profession. This implies that majority of the newly selected TCs have motivated interest for teaching professions.

Lastly, about 16 and 16 (23.5\% and 23.5\%) of respondents were disagree and strongly disagree respectively, that the newly $\mathrm{TC}$, achievement in classroom learning was higher than the former TC whereas about 6 and 10 (8.8\% and 14.7\%) of respondents were strongly agree and agree respectively, that the newly TC academic achievement was higher than the former TC. This result shows that the newly TC were lower than the former TC in classroom academic achievement. This result is supported with table 9 and 10 below.

\subsection{The Newly and the Former Teachers Candidate's Classroom Achievement}

This section deals with comparing classroom achievement of the newly teachers candidate (grade point) of the year 2018/2011 E.C and the former teachers candidate of the year 2016/2009E.Cand 2017/2010E.C measured by GPA described under table 9 and 10. The numbers of students were top 20 in their academic achievement from each college.

Table9. The newly and 2016/2009 E.C students' classroom achievement

\begin{tabular}{|l|l|l|l|l|l|l|}
\hline \multicolumn{1}{|c|}{ Variables } & $\mathrm{N}$ & Range & Minimum & Maximum & Mean & Std. Deviation \\
\hline $\begin{array}{l}\text { Student achievement in } \\
\text { classroom 2016/2009 E.C }\end{array}$ & 20 & .89 & 2.83 & 3.72 & 3.2510 & .27703 \\
\hline $\begin{array}{l}\text { Students achievement in } \\
\text { classroom 2018/ 2011 E.C }\end{array}$ & 20 & 1.41 & 2.24 & 3.65 & 2.9005 & .44109 \\
\hline
\end{tabular}


From the above table, $N=20$, in 2016/2009 E.C the mean of TC is CGPA was 3.25 but in 2018/2011 E.C $=2.9$ and in 2016/2009 E.C $\mathrm{R}=.89$ and in 2018/2011E.C. $\mathrm{R}=1.41$ and also $\mathrm{SD}=.27$ and .44 in 2009 and 2011 respectively. In 2016/2009 E.C (Minimum=2.83 and maximum= 3.72) and in 2018/2011 E.C (Minimum=2.24 and maximum= 3.65). Therefore the result shows that, with comparison of CGPA of between the two year, (2016/2009 E.C and 2018/2011 E.C) TC of 2018/2011 E.C were lower than TC of 2016/2009 E.C with the difference of 0.59 and 0.07 in minimum and maximum score respectively. In the case of mean score the 2016/2009 E.C TC was great achiever than $2018 / 2011$ E.C TC by 0.35 . In reference to minimum and maximum score ' $R$ ' of 2009 TC is lower than 2018/2011E.C TC, it mean that based on minimum and maximum score TC of 2016/2009 E.C were higher achiever than TC of 2018/201 E.C. SD of TC of 2016/2009 E.C is less than in TC of 2018/2011 E.C. This means, each teacher candidateCGPA deviated from their mean was far apart in 2011 than in 2009. Generally we can conclude from this, the newly teacher candidatesof 2018/ 2011E.Cis lower achiever than 2009 teacher candidates.

Table10. The newly and 2017/2010 students' and academic achievement

\begin{tabular}{|l|l|l|l|l|l|l|}
\hline Variables & N & Range & Minimum & Maximum & Mean & Std. Deviation \\
\hline $\begin{array}{l}\text { Students achievement in } \\
\text { classroom 2017/2010 E.C }\end{array}$ & 20 & .78 & 3.22 & 4.00 & 3.6405 & .24733 \\
\hline $\begin{array}{l}\text { Students achievement in } \\
\text { classroom 2018/2011 E.C }\end{array}$ & 20 & 1.41 & 2.24 & 3.65 & 2.9005 & .44109 \\
\hline
\end{tabular}

According to table $10, \mathrm{~N}=20$ in comparison of the two years classroom achievement in terms of mean 2017/2010 E.C=3.64, 2018/2011 E.C $=2.9$, with SD 2017/2010 E.C $=.24,2018 / 2011$ E.C $=.44$, regarding R 2017/2010 E.C $=.78,2018 / 2011$ E.C $=1.41$ in relation with maximum (4.00 and 3.65) and minimum (3.22 and 2.24) in 2017/2010 E.C and 2018/2011E.C year respectively. This result shows that in 2017/2010 E.C there was higher achiever than in 2018/2011 E.C. Depending on the result of maximum and minimum grade of TC, ' $\mathrm{R}$ ' describe that the TC of 2010 were more achiever than TC of 2018/2011E.C because of smaller 'R'. The aggregate achievement of students is higher in 2010 than in 2011.Standardeviation of students achievement was less in 2017/2010 than 2018/2011E.C

\section{DISCUSSION}

\subsection{Demographic Characteristics of Respondents}

The proportion of males and females was not balanced 66 and 2 (male 97.05\% and female 2.95\%). This implies that those female lecturers are very little in number in CTE'S. Concerning level of education, majority of the lecturers $56(82.4 \%)$ were second degree holders. This data shows that more of the lecturers were masters' holders and they full fill the higher education criteria for training diploma as well as degree teacher candidates. More of the respondents' experience was above 20 years that account 38 (55.9\%). So, this implies that the lecturers had sufficient work experience. The finding of Covino\&Iwanicki, (1996) ensured that experienced teachers have increased depth ofunderstanding of the content and how to teach and apply it .Regarding experience in selection of TC indicated in a years, majority of lecturers were participated in selection of TC, about $18(26.5 \%)$, it means that they are familiar with different selection guidelines documents (See table 2 and 3).

\subsection{Perception of Lecturers Towards the Guideline Recruitment Criteria}

Majority of respondents 34 (50\%) were not satisfied on the preparation of the guideline. Therefore it is possible to conclude from this, the way in which the guideline recruitment criteria prepared is wrong.

The lecturers in their open ended questionnaire response support this view that to prepare the guide line the administration including vise dean alone is not recommendable; the lecturers were the right person in preparation

More of respondents $44(64.7 \%)$ were react positively towards on the selection criteria of the guideline but not least number of $22(32.4 \%)$ respondents were not recognized that the guideline recruitment criteria. Therefore from this, it is concluded that more of the respondents were react positively towards on the selection criteria of the guideline but it need improvement. 
The open ended questionnaire shows that the guideline did not invite higher academic achievement students that explained redundantly by lecturers. This means the criteria in the guideline needed some improvement.

Majority of the lecturers $40(58 \%)$ were realized that the guideline recruitment criteria was not invite higher academic achiever. Therefore, this implies more respondents were agreeing on this issue that the recruitment criteria of the guideline not invite higher academic achiever.

The response from newly TC of focused group discussion regarding the above issue that; higher academic achiever students haven't an interest to be a teacher because of currently paid of monthly salary of teachers and the like in teaching profession. The criteria itself guide to invite lower academic achiever, therefore it needs some amendment. The condition in teaching profession is unattractive that is why higher academic achiever were not interested. As the finding of Ayesha Bashiruddin (2018) indicated that whenever we were asked what we want to become in the future, most of us used to say engineers and doctors. No one ever said teacher. This is a very important issue and is still true today. Students never say that they want to be teachers. Maybe, because teachers are not given the status they should have or due to the low economic status of the profession.

Majority of respondents 38 (55.9\%) revealed that responded that the candidate for teachers have an interest to be a teachers. From this it is concluded that more of the respondents were agree on the interest to be a teaching profession. Ayesha Bashiruddin (2018) stated that most of the young individuals who decided to become teachers did so because they thought of it as a respectable profession in society and knowledgeable.

The response from focused group discussion of TC; more of the newly teachers candidate have an interest to be a teacher for so many reasons: Teaching profession is a fundamental for all profession, to cultivate learned society, to change our society from the level of illiterate to literate, for proudness of teaching profession because teacher is a father for all people and profession as well as knowledgeable throughout his/her lifespan. As the finding of Ayesha Bashiruddin (2018) indicates that, these young individuals developed this perception to be a teacher because they observed in their communities how the teachers were empowered because they got a lot of respect in the society; many narratives show that this was because they were considered to be wise and knowledgeable and teachers' positive qualities and personalities that inspired them to become teachers.

Lastly majority $60(88.7 \%)$ of respondents ensure there is no evidence put on the guideline as a criterion to identify the interest of the candidate to be a teacher. Therefore from this it, conclude that there is no evidence put on the guideline as a criterion to identify the interest of the candidate to be a teacher. As Lortie cited in Ayesha Bashiruddin (2018) teachers start their professional preparation early in life, their entire school experience contributes to their work socialization. Additionally he proposed that the prospective teachers tend to gather all the images of teaching in their life of being learners. The role models that they have seen become prominent when they start teaching. Hence, their biography supports their teaching (See table 4).

\subsection{The Incorporation of the Guideline Criteria}

Employees do not magically appear when the need arises; they must be recruited, selected, and retained. The recruitment of individuals into the teaching profession is the first step in securing an effective teacher for every classroom Dozier \&Bertotti cited in James and Jennifer (2006) describe that "Selecting the most qualified applicants is the second challenge, followed by retaining effective employees once they are working for the school district".

Majority of the respondents 40(58.9\%) were disagree that the content of the guideline was not focus on the ethics of the teaching profession. Therefore it's concluded from this point, the guideline was not incorporated the professional ethics of teaching while preparing. More of the respondents $32(47.1 \%)$ were agree that the criteria in the guideline was not invite effective and quantity teachers candidate. From this result it's concluded that the criteria in the guideline don't incorporate to select effective and quantity teachers in accordance to demand of the region (See table 5). As the annual plan of the OEB (2012) indicated that diploma teacher's demand of the region was 8230 (impossible to get demand of teachers for 2014 E.C) .Therefore the researcher enforced to take this data to the year of 2014 E.C. And the supply of diploma teachers for 2014 E.C will be around 2476. Therefore 
according to the demand and supply of the diploma teachers of the region, the scarcity of 5754 diploma teachers will face the region after two graduation years. i.e 2014 E.C. Likewise Effective teacher is the idea that a teacher cares about students as individual and communicates that ethic by creating thoughtfully planned, executed, interactive, enthusiastic, motivated, fair, respectful, reflective and assessed instructional opportunities in a productive classroom environment an effort to increase the achievement of each (Collinson, Killeavy, \& Stephenson, 1999).

The criterion in the guideline was not assessing communicative skill of teachers candidate with respondents of 40(58.9\%). This result implies the guideline was not considering communication skill of the teacher candidates in good manner but there is sense of communication skill assessment that account about $12.9 \%$ (See table 5). Different literatures are expressing that select effective teacher communication skill of TC should be necessary. This result is supported with the finding of DarlingHammond cited in James and Jennifer (2006) that "teachers make connections with their students through words and actions". A teacher's verbal ability has a positive effect on student achievement, as the ability to communicate content knowledge and belief in students is vital to teaching and learning.

On the table five, $36(54.6 \%)$ of the respondents were agree that the guideline concern about the inclusive education and only $12(18.2 \%)$ were disagree on this issue. This implies that the guideline was invite inclusive education and serves for anybody whose fulfill the criteria. As Cascio cited in James and Jennifer (2006) notes that "Although no law has ever attempted to define precisely the term discrimination and unfairin the employment context it can be viewed broadly as the giving of an unfair advantage (or disadvantage) to the members of a particular group in comparison with the members of other groups".

Lastly the majority of the respondents $40(58.9 \%)$ were agree that the guideline is not designed to include different teaching methods and assessment in subject specific. This result shows that there is no practical teaching methods and assessment in the guideline with specific area of subject(See table 5).The finding of James and Jennifer (2006) shows this, tomake the best possible selectionpermit observation of teacher applicants in an instructional setting grounded with related documents (e.g., résumé, letters of recommendation, Praxis scores) and the selection interview.

\subsection{Responses of Lecturers on the Newly Teacher Candidates` Performance During Selection}

The finding shows that more $50(73.5 \%)$ of the respondents were recognized the newly selected teachers ' candidates had tested with their ability to convey knowledge during selection. The result shows that almost about 48 (70.6\%) of the lecturers were convinced that the newly TC was assessed their communication skill but still there is a gag to assess communication skill of TC while selection. The finding found that about $44(66.6 \%)$ of the respondents were accepted the newly selected candidates' knowledge of subject matter. The majority of respondent realized that almost more than half percent $36(54.5 \%)$ of the respondents were realized that newly TC was selected with clear defined criterion. The result shows that there no regular central control while selection processes were ongoing. It's possible to conclude that more of the respondents realize that the test prepared has depended on the minimum learning competency (See table 6 and 7). The above finding also supported with finding of Ruth Nees (2014) that a person who desired to be a teacher/guide boys and girls should possess love the child and his country, reasonable degree of proficiency in physical fitness, academic intelligence, social adaption, good voice quality, skill in fundamental process, understanding culture of society, reasonable degree of extraversion and leadership quality.

\subsection{Lecturers Responses on Performance of Newly Teacher Candidates in Training Processes}

This finding shows more 38 (55.9\%) of the respondents were argued that the newly TC have the potential to promote reflection, discussion, simulation and analysis of cases and situations during training process and $48(70.8 \%)$ the respondents also ensure that the process and system of teaching and learning methods introduced in the colleges were more depend on the TC in order to develop their capacity. The finding shows that about $44(64.7 \%)$ of the respondents were realized that, there is a focus of newly TC in induction period of first year personal and professional developments but it 
improvement had been needed.The finding also revealed that majority $26(38.2 \%)$ of the selected candidates has motivated interest for teaching professions. The result shows that more respondents about $44(64.7 \%)$ were realized that processes and systems in CTE's facilitate the development of the core values and professional commitments which are set out in the professional conduct for teachers. (See table 8). As Zimmerman cited HeferBembenutty, Marie C. White and Miriam R. Vélez (2015)Students are adapt self-generated thoughts, feelings, and actionsthat are systematically designed to affect learning of knowledge and skillsconstrues self-regulated learners as individualswho are cognitively, motivationally, and behaviorally active participants in theirown learning process.

Finally the finding shows that in classroom academic achievement the newly TC, were lower achiever than the former TC as indicated in table 9 and 10.

\section{SUMMARY,CONCLUSION AND RECOMMENDATION}

\subsection{Summary}

The main purpose of this study was to evaluate the guideline and recruitment criteria of selection teacher candidates of CTE's in Oromia National Regional State that prepared in 2018/2011 E.C. In line with this, the following basic questions were raised.

1. What is the perception of college's Lecturers towards the recruitment criteria and the guideline?

2. What extent the newly teacher candidates (2018/2011 E.C) achieve academically in relative to the former teacher candidates (2016-2017/2009 and 2010 E.C) in classroom test?

3. What are the gaps those incorporate in the guideline and its impact as a criterion?

4. What are the contributions of colleges of teacher's education to capacitate the teacher candidates to be effective teacher?

Inordertoconductstudybasedonthebasicquestions, 137 samples (68 lecturers and 69 newly teachers candidates) were randomly selected from FCTE, SSNCTE and NCTE as samples of college those selected through randomization.In order to collect the necessary data for the study, developed questionnaire as open and closed ended and focused grouped discussion was used. Thestatisticaltoolsusedinthestudy weredescriptive statistics of frequency and percentage for measuring the demographic characteristic and perception of respondents and range, mean and standard deviation was applied for comparison of academic achievement of newly teacher candidates with the former one.

Based on the finding of the study, the following brief summary was done.

More of the lecturers were masters' holders and they full fill the higher education criteria for training of diploma as well as degree teacher candidates and also they are well experienced mainly above 20 years those account 38 (55.9\%) of them.

Concerning years of participation in selection of newly candidate about 14 (20.6\%), 2 (2.9\%), 18 $(26.5 \%), 4(11.8 \%)$ and $26(38.2 \%)$ of them were participated from 1-2 years,3-4 , 5-6, 7-8 and above 9 years respectively. This result implies that more lecturers $26(38.2 \%)$ were experienced in selecting teacher candidates for more than 9 years; this indicated that they are familiar with different selection guidelines and criteria that prepared at different time.

More of the Lecturers were agree on the selection criteria of the guideline for its correctness but they argued that the way in which the guideline recruitment criteria prepared is wrong.

More of the respondents were agreed on the issue that the recruitment criteria of the guideline not invite higher academic achiever and also their GPA shows the same idea. Even though the newly candidate were not higher academic achiever but they have an interest to be a teachers.

There is no practical assessment as a teacher's candidate and assessing their communication skill and ethics towards teaching profession were not satisfactory in the guideline while preparing.

The criteria set in the guideline don't incorporate to select more newly teachers candidate in quantity in accordance to demand of the region that shows with the scarcity of 5754 diploma teachers for the year 2014 E.C but the criteria were clear and define. And it highly considers and invites special need teachers' candidates. The prepared test in selection for candidate were related to minimum learning competency but there is no regular central control mechanism were selection processes were ongoing. 
The process and system introduced in the colleges were a chance for candidates to develop their capacity but the newly teachers candidates' personal and professional developments in training processes of induction period still need their deep attention.

Not only the guideline criterion to recruit candidates has a problem but also the teacher training curriculum has at least its own impact on the professional development of the candidates. In CTE the implementing quality assurance and evaluation system were mandatory to screen out competent teachers.

Lecturers in CTE should be not only teach the teachers candidate but also participate on research activities to encourage and speed up the continuous renewal of education with professional development

\subsection{Conclusion}

An Evaluation of Guideline and Recruitment Criteria selection of Teacher Candidates of College of Teachers Education in OromiaNational Regional State, based on the finding the following implications wereconcluded.

The proportion of males and females was not balanced. From this it may conclude thatthose female lecturers are very little in number than male lecturers in CTE'S. Concerning level of education, more respondents was master's holders. This result lead us to concluded that more of the lecturers were full fill the higher education criteria for training diploma as well as degree teacher's candidates. Additional more lecturers had sufficient work experience. Regarding years of respondents participated in selection of newly TC, more lecturers were familiar with different selection guidelines and criteria that serve for 9 years (See table 2).

Regarding the guideline document, the finding shows that the lecturers were accepting the guideline document positively but not convinced the way the guideline prepared. Therefore it is possible to conclude from this, even though the guideline document had accepted positively but the way in which the guideline recruitment criteria prepared was wrong. The result shows that, the lecturers realized that the criteria in the guideline not invite higher academic achiever students, in line with newly TC argument of focused group discussion; this is because of unattractive condition like salary in teaching profession. Additional the finding shows that the lecturers approved that the newly selected TC have an interest to be a teachers, the newly TC argued that teacher is a father for all people, fundamental profession for others, an agent to change illiterate society and to be proudness of the profession enforced them to be a teacher and finally there is no evidence in the guideline document that describe either the TC have an interest or not to be a teacher (Refer table 2 and focused group discussion finding).

Majority of the respondents (58.8\%) were realized that the content of the guideline was not focus on the ethics of the teaching professions but least number of respondent about $12(17.6 \%)$ realized this. Therefore it's concluded from this point, the guideline was not attachment with the professional ethics of teaching while preparing. More lecturers responded that the guideline incorporate to assessed communicative skill of teachers candidate with respondents of $8(11.7 \%)$ but $46(67.6 \%)$ of the respondents were not observed this point as a criteria in the guideline. So it is possible to conclude that the guideline was not incorporate to assess the communication skill of newly teacher candidates. $32(47.1 \%)$ of the respondents were realized that the criteria in the guideline was not invite effective and quantity teacher candidates, on the other hands 20 (29.4\%) of them were agree that the criteria was highly invite effective and quantity teachers. From this result it's concluded that the criteria in the guideline doesn't incorporate to select effective newly TC relatively to the former candidate, this is supported with the finding of table 9 and 10 and according to the demand and supply of the diploma teachers of the region, the scarcity of 5754 diploma teachers will face the region after two graduation years. i.e. 2014 E.C

$36(54.6 \%)$ of the respondents were realized that the guideline concern about the inclusive education but only 12(18.2\%) were disagree on this issue. As a conclusion of this point the guideline was prepared in considering inclusive education. About $16(23.5 \%)$ of the respondents were agree that there is different methods of teaching and assessment methods incorporate in the guideline with 
specific subject but $40(58.9 \%)$ were not. Therefore it is possible to conclude this point; there are no practical teaching and assessment methods in the guideline with specific area of subject (See table 5).

More respondents were recognized that the newly selected teacher candidates had tested with their ability to convey knowledge and communication skill during selection. The finding of this study indicates, there is written assessment to evaluate the newly TC knowledge and communication skill while selection but still there is gap. More lecturers (66.6\%) were convinced the knowledge of subject matter of the newly TC. This finding shows that even though the newly teacher candidates was lower achiever than the former one but the knowledge they acquire through placement assessment is so enough for college program because more lecturers (76.6\%) support this idea that the administered test to assess their knowledge level was highly related with minimum learning competency. Majority of the respondents $(47 \%)$ agree but $26.5 \%$ were not agree that on the issue of central control mechanisms. This finding shows that there no regular central control while selection processes were ongoing (see table 6 and 7)

The finding shows us the newly TC promote reflection, discussion, simulation and analysis of cases and situations and the process of teaching and learning mainly depend up on TC during training process. It is conclude that newly $\mathrm{TC}$ has the potential to promote reflection, discussion, simulation and analysis of cases and situations and more of the teaching and learning process is depending on TC during training process in the classroom. The result also shows that the respondents were realized attention in induction period of first year personal and professional developments has been needed. From this it may conclude that, after the colleges registration of first year schedule there is loss of attention of newly TC regarding personal and professional developments. The finding shows that the processes and systems in CTE's facilitate the development of core values and professional commitments which are set out in the professional conduct for teachers. It is conclude that there are the core values and professional commitments the TC learn from the CTE's Lecturers. The finding also shows that majority of the selected candidates have motivated interest for teaching profession. From this it may conclude that lecturers of the CTE's observed that the newly TC has high motivation interest for teaching profession (See table 8). The result also shows that the newly TC were least achiever in classroom academic achievement than 2009 TC with the difference of 0.59 and 0.07 in minimum and maximum score respectively. Likewise the newly TC of 2018/2011E.C is least achiever in classroom academic achievement than 2017/2010 E.C TC, with the difference of .78 and 1.41 minimum and maximum respectively. From this it may concluded that the newly TC were low achiever in classroom academic achievement than the TC of two consecutive years of 2016/2009E.C and 2017/2010 E.C.

\subsection{Recommendation}

There is a trend in Oromia Education Bureau to re-preparation of the guideline document yearly. Therefore, it can be stated that even though the guideline document was accepted by lecturers of the study area some many improvement should be needed. For this reasons it would be important to recommend some suggestion for concerned bodies.

- In Oromia Colleges of Teachers Education female lecturers were small. So the concerned bodies should have responsible to increase female lecturers in the colleges while the is a vacancy with keeping a rule and regulation of civil servant of the region/Jildii/ and at national level

- Experienced lecturers in college those participated in selection of teacher candidates for many years should be participating while the guideline document of selection have be preparing.

- The entirely document should be assess authentically especially with specified subject matter, consider ethical conduct of teachers profession with reference to Oromo culture, the criteria should be focused to invite higher academic achiever.

- The guideline document should also assess the communicate skill of the newly teachers candidate as a criteria with good standard.

- Each Teacher candidate should be come with evidence that shows their interest to be a teacher from school of teacher's profession club. If the club is not there, it should be established and documented the profile of students in good manner. 
- The region may face scarcity of teachers after three years because the evaluated documents admitted small number of teacher's candidate relative to the demand of teachers therefore, OEB should be prepared students from degree program for actual teaching for the year of 2020/2014 E.C.

- Lecturers in the colleges should be focused on the reflection as an assessment methods as a part of continuous assessment and sometimes use analysis level of cognitive domain in teaching as well as in assessment depend on competency of the course.

- The vacancy notice invite all individual including the especial need teachers candidate in terms of physical condition with support of inclusive education should be encourage in revision of the guideline.

- The guideline incorporate the criteria that assess knowledge aspects of the teachers candidate that related to their competency should be encouraged for future

- The central control mechanism should be applied for encouragement of the colleges administration and lecturers in the selection process.

- Lecturers of the colleges on their behaves should do efficiently for enhancing newly teacher candidate as to effective teachers at process of training in colleges

- The colleges administration should be introduce a session for teachers' core values as a profession related with Oromo culture and commitments either at beginning or graduation years and inviting experienced teachers to share their skill and experience as a model for motivating the graduate candidate.

- To invite high academic achiever in teaching profession good plat form like monthly salary and the like should be improved for the newly applicant. Additionally the newly applicant profile should be in the guideline that set as a criteria dealing with entrance examination result should be improved from the year 2018/ 2011 E.C and it should be somewhat consistency with their transcript and previous national examination result.

- Further researches may be conducted at higher level and on a larger number of Participants, so that it may be found out whe the there exist further finding on evaluation of guideline and recruitment criteria of diploma teacher candidatesof Collegeof teachers education in OromiaNational Regional State that prepared in 2018/2011 E.C.

\section{REFERENCES}

[1] Ayesha Bashiruddin (2018) Teacher Development and Teacher Education in Developing Countries On Becoming and Being a Teacher. United Kingdom. Macmillan Publishers Ltd.

[2] BBO (2012). The annual plan of Oromia Education Bureau: Unpublished.

[3] BoFEDO(2010). Finance and Economic Development Bureau of Oromia Regional Government- GIS Data Base.

[4] Collinson, V., Killeavy, M., \& Stephenson, H. J. (1999). Exemplary teachers: Practicing an ethic of care in England, Ireland, and the United States. Journal for a Just and Caring Education, 5(4), 349-366.

[5] Covino, E. A., \&Iwanicki, E. F. (1996). Experienced teachers: Their constructs of effective Teaching. Journal of Personnel Evaluation in Education, 10(4), 325-363.

[6] HeferBembenutty, Marie C. White and Miriam R. Vélez (2015) Developing Self-regulation of Learning and Teaching Skills among Teacher Candidates. New York: Springer.

[7] James H. Stronge and Jennifer L. Hindman (2006) the teacher quality index: protocol for teachers selection; United States of America. ASCD publications present.

[8] KrejcieR. And Morgan D. (1970) Educational and Psychological Measurement: University of Minnesota, Duluth.

[9] Ministry of Education (1994). Education and Training Policy, Transitional Government of Ethiopia, Addis Ababa, Ethiopia.

[10] Robert L. Mathis and John H. Jackson (2010) Human Resource management (13 ${ }^{\text {th }}$ edition).USA: SouthWestern, Cengage Learning.

[11] Ruth Nees (1950).The Selective Recruitment and Orientation of Future Elementary Teachers: A Program for High School Seniors In Las Cruces, New Mexico: Proq UestLlc 
An Evaluation of Guideline and Recruitment Criteria of Selection of Teacher Candidates of College of Teachers Education in Oromia National Regional State of the Year 2018

[12] TGE. (1994).The New Education and Training Policy. Addis Ababa, St. George Printing press

[13] UNESCO (2006): Teachers and educational quality: Monitoring global need 2015 Institute for Statistics, Montreal, ImprimerieL'Empreinte

[14] UNESCO (2008).EFA Global Monitoring Report 2008; Education for all by 2015; Will we make it? UNESCO, Paris.

[15] UNESCO (2016) eAtlas of Teachers: Institute for Statistics database Montreal, Imprimerie L'Empreinte

\section{AUTHOR'S BIOGRAPHY}

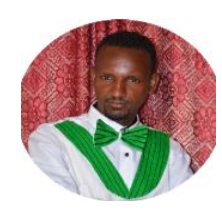

Gadisa Wando Shaka, Lecturer and Researcher at Fitche College of Teachers Education, Stream of Education, Department of Psychology, Ethiopia, Oromia, Fitche

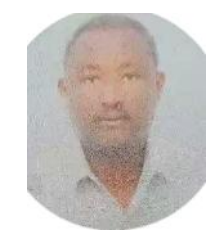

Dawit Tadese Mekonin Lecturer and Researcher at Fitche College of Teachers Education, Stream of Social Science, Department of Geography, Ethiopia, Oromia, Fitche

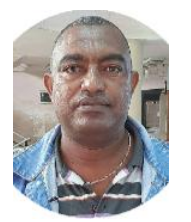

Mosisa Dejene Chala Directorate of Higher Education, Team leader of Research at Oromia Education Bureau, Ethiopia, Finfinne

Citation: Gadisa Wando Shaka, et.al. " An Evaluation of Guideline and Recruitment Criteria of Selection of Teacher Candidates of College of Teachers Education in Oromia National Regional State of the Year 2018" International Journal of Humanities Social Sciences and Education (IJHSSE), vol 7, no. 9, 2020, pp. 14-31. doi: https://doi.org/10.20431/2349-0381.0709002.

Copyright: (c) 2020 Authors. This is an open-access article distributed under the terms of the Creative Commons Attribution License, which permits unrestricted use, distribution, and reproduction in any medium, provided the original author and source are credited. 